\title{
Audit of movable and immovable property foreigners in Iran
}

\author{
Shaban Mohammadi ${ }^{1}{ }^{*}$, Fatemeh Zahmati $^{2}$, Ali Mohammadi ${ }^{3}$ \\ ${ }^{1}$ MA Student, Accounting, Hakim Nezami University of Quchan, Quchan, Iran \\ ${ }^{2}$ Department of Law, Damghan Branch, Islamic Azad University of Damghan, Damghan, Iran \\ ${ }^{3}$ Department of Law, Damghan Branch, Islamic Azad University, Damghan, Iran \\ *Corresponding author E-mail: shaban1362@gmail.com
}

\begin{abstract}
This article related to the acquisition of immovable property by foreigners and audit of the country of Iran. first, a description of the movable and immovable property provided by the auditors of the situation in Iran. immovable property owned by foreign nationals in accordance with the conventions or that of any of the laws of Iran. raw materials of the civil law relating to immovable property to foreign nationals decide about translation of the original material of the French civil code. with the progress of human civilization and the development of communities and increasing international exchanges and communications and other foreign nationals in any country of the United need to be at least more privacy for citizens known interior there is a benefit. Foreign nationals have the right to freedom of movement and the right to engage in commerce and trade and the exchange of marriage and divorce and property ownership whether movable or immovable have the ability to work and live in the community are not alien to them. today, as in most countries, even the acquisition of immovable property to foreigners and states that this right is recognized foreigners are known to have been in the minority.
\end{abstract}

Keywords: Immovable Property; Foreigners; Property Audit; Tax.

\section{Introduction}

Countries that immigrants are forced to offer a broader range of rights to foreign nationals from countries that Especially immigrants, do not accept the position and considerations as to attract and encourage people to migrate to the Facilities were granted. Countries can be divided into three categories in this respect. Mouse unconditionally entitled to the enjoyment of the rights of the first countries to recognize foreign countries like America and England. the second category of countries that span the political counter-trade clause that these rights have been known to outsiders. third countries where the rights of foreign nationals are those who practice the law or the law; their respective countries have recognized the rights to foreigners. This system requires a contract to be No diplomatic and also cause the system to maintain a balance between the countries with other countries will be accepted. the fourth category of countries that are generally foreign nationals unless they have every right to enjoy the rights conferred by law disclaimer foreign nationals or nationals assigned to its interior. Restrictions on ownership of immovable property for nationals Austrian Foreign Law in Romania Fourth of July 1924 pursuant to Article 7 of the constitution in 1879 and Swedish law on May 30 1916 and July 18, 1867 Turkish law and law in Mexico, Poland, February 1851 and 24 March 1920 on the Law of the Federal German and some foreign countries While in Japan, foreigners can be deprived of the right to possession of the immovable property. Philosophy that governments Particularly in respect of immovable property more cautious towards foreigners is considered necessary Granting unconditional and extent of this right may involve damage to the country and led to the intervention of a government Foreign nationals in foreign country has the right to be. Article 8 of the Civil Code states: ((immovable property that is owned or foreign nationals in Iran, according to the conventions each order is subject to the laws of Iran.)) Of the complete translation of paragraph 2 of Article III of the French Civil Code contains two basic parts. First, the right of ownership of immovable property to foreigners, and the treaty is. Secondly, this property is necessary for the function of law. Immovable property: 1. Inland Enforcement (the location of the object) to the immovable property has been accepted for the following reasons ever. 2. The duty to maintain order and ensure the transactions relating to immovable property in the state that the property is located in the territory of the property. 3. By law, the provisions relating to registration of immovable and immovable rights declaration drawn up. 4. Law Enforcement immovable place an order that is the basic condition to implement than it exported. Philosophy civil law limiting foreign ownership than other amouli Real estate is canceled before capitulation and the weakness of the central government Foreigners successful acquisition and acquisition of immovable property and cadastral Were plentiful and it was further weakening of the central government. So I canceled after the capitulation in immovable property law swivels, anc Aliens in 1310 and one of the twelve notes of Parliament passed whereby foreign nationals are required to sell properties His farm and property in accordance with Article 8 of the Civil Code of Foreign Nationals There was a contract and therefore subject to the Treaty and in accordance with Article Nationals Foreign nationals other than through the administration of the Treaty to allow them to take possession of property other Movable in Iran. Not be accepted for review. Save the files to be compatible with many versions of squeeze more text into a limited number of pages. 


\section{Immovable property by foreigners}

foreigners according to the conventions of ownership of immovable property which is the subject of legislation. Government of Iran Foreigners to immovable property in Roman law is derived from the old rule whereby immovable function Regulation of their occurrence. as we already mentioned in the second paragraph of article 8 of the Civil Code of translated material France's third law is the text of which reads: This is the text of topics in all countries accepted Because the property is located in an area subject to the other provisions of these rules are the many problems involving Is. In addition, the principle of the rule of law is the law of any country, territory, according to the circumstances and Location and characteristics of racial, ethnic and religious traditions and national legislation of the country situation and are therefore Should in principle to all persons and property located in its territory and influence their government and immovable property of every If the other provisions of the country in which they are located, discomfort and conflict of laws and the lack of trust there Comes. If the real property is located in one of the owner of the Iraqi law and Another criterion to validate that it is a citizen of India is technically and legally regulated many forms That the people should know the regulations of all countries in this regard, in addition to the registration of immovable property situated in A country other than the function of the law is also not practical. In addition, any immovable property situated in the country Credit is the owner of the other country's rules at the time of the transfer or sale of such property and mortgage bugs Variations occur and cause corrosion to the legal life of society. Rules and including the last two characters This means that as long as the copies are not any law to all persons and property located in the territory. And therefore immovable property located in any country is subject to the laws of that country and in accordance with the principle of personal Iran Iran is in principle subject to the laws of any exceptions, including the exceptional friction The theory of public order and the laws relating to immovable property laws relating to public order so Immovable property subject to the personal rule of law and rules out the existence of its own. As a result of this is the immovable property subject to the regulations and their location. must specify the scope of the rule, and those who have not to this rule, according to our survey, the following provisions of this rule. 1. All funds voluntary acquisition of immovable property such as mortgage, rent and sales Hebe. 2. Legal aspects of the acquisition of immovable property such as acquisition time and the result of continuous occupation. 3 . The rights of the objective and the subjective preference, mortgage, easement or other rights. This means that the creation and fall of the in principle, such rights and the general rules and regulations of the place is yours. Article 966 of the Civil Code About this provides: ((seizure of property and other rights in movable or immovable objects will be subject to the law of the country the objects are located. However, the transport of a movable object from country to country can no longer legal The parties may by law have studied the site of the first part of it brings prejudice.)) That the first part of the material to adhere to the principles set out above, and the second is related to the acquired rights respected international Is. In other cases, this rule is not applied within a transaction, such as the rejection of immovable property qualification Parties to the transaction would be subject to the law of the place does not belong to anyone but the capacity of his own country's rules The meaning of Article 962 of the Civil Code as follows ((detection capacity anyone to trade in Of his government would be ...)) is stipulated. But the materials wherein a foreign national in action Do you possess the legal capacity to act in accordance with their national law, not the law, but according to the rules Meet the qualification criteria of qualification recognized him and this is the exception to the rule. As well as contracts related to Immovable property shall be governed by the provisions of the contract and location of property (Article 968 of the Civil Code) and As well as the provisions of the document but the document also function under Article 2138 of the French Civil Code Exceptions .
To this principle because, according to Article compiled: ((mortgage contract when it is right to immovable property the notary and registered in France, unless the treaty otherwise stipulated order Have.)) So if the mortgage contract to immovable property located in France is located in a foreign country and The French government and the contractor shall prescribe such legal action there is a contract Based on the material in French civil law is subject to invalidation. Under the 1760 agreement between France and Italy between France and Belgium on 8 July 1899 in accordance with the contract has been agreed that the mortgage contract in Belgium and Italy if it is realized in accordance with Italy and Belgium and the immovable property located in France Is valid. Apart from the foregoing that the opportunity to apply the law of another case where the property is not available S., and it is thought that in a country where there are no rules, for example, how can property other there are no real rules function and a sample contract in this case might arise backward communities. Breakdown of movable and immovable property the division of movable and immovable property are as follows: Foreigners can freely in their own immovable property Transfer of immovable property should be made by an official document, but is not necessary in the case of movable property formal document. $\mathrm{n}$ is limited to immovable property. To deal with claims relating to immovable, the competent court is the immovable property is located in the area. Easement for the immovable property. Women of movable property generally inherited, but he is very limited contribution of immovable property.

\section{Individuals subject tax}

Article 1 the following persons are taxable: 1 . All owners of the property, whether real or legal persons or their property in accordance with the provisions of Chapter II. 2. Any person living in Iran than in any income or education abroad is. 3. Any natural person residing abroad to study all the income in the country. (4) Any legal person in Iran or Iranians to all income that is studying abroad. or to display or any other income as they are) of Iran was studying. The 1328 regulations on working conditions of foreigners in there and only the relevant provisions Approval had been granted legal residence or citizenship application was acquired in Iran. But overall we can say that the first foreigners to work within Iran's borders were not so difficult. The only limitations the jobs that would be limited to citizens of the Interior or the state or grant concessions subject to Is the natural and legal persons. But gradually, the threat of immigration of foreign workers for employment of nationals, emotion and Regulations adopted.

\section{Employment problems foreigners}

To limit the employment of aliens in the market, there are many reasons. Illegal Employment of Foreigners Resident of one of the causes of the high rate of unemployment in the country as thousands of job opportunities to the youth of this country is used. Foreign labor force also decreases the rate of job security in the labor market, the lack of mental health Iranian labor, employment, culture change, reduced gross national income through the transfer and exchange of business free expertise in the industry. It should be noted that in the absence of Iranian nationals in employment faced with restrictions Rules and regulations for dealing with illegal employment of foreigners, in practice it can be seen that the inspectors visit Work, employers have been able to determine the penalty that the mostly foreign workers to pass and this Problems in dealing with the private sector has created offending. When a paper is cited, the reference list should include authors' surnames and initials, date of publication, title of paper, name of journal in full (not abbreviated), volume number, and first and last page numbers. Example: Watson R, Hoogbruin AL, Rumeu C, Beunza M, Barbarin B, MacDonald J \& McReady T (2003) Differences and similarities in the perception of caring between Spanish and United Kingdom nurses. Journal of Clinical Nursing 12, 85-92. 


\section{Audit punishment of alien workers}

One reason for the widespread presence of illegal workers, employers supports the workers. It seems that the current penalties can discourage businesses from using foreign workers. Another reason, employers are unfamiliar with this practice is illegal punishment. Foreigners without permission are prohibited and the employers hiring illegal workshops that bring to hire foreigners without work permits for illegal employment of foreign workers are equivalent to 10 times the minimum wage a daily fine of. Employers also leave after notification to the employment of foreigners without permits fines to settle accounts with them, and they expel them. Delinquent employers in terms of features and much offense to imprisonment from 91 days to 180 days will be sentenced. The Labor Department announced far the courts can Foreigners in case of violation, or bans their entry into the country to demand the dismissal of the request. Employers should refrain from hiring and employment of foreigners without work permits and government to seek solutions to illegal workers return to their own country. All workshops across the country to identify foreign nationals without a work permit by the Department of Cooperatives, Labour and Social Welfare inspected. the total budget of the action. should be noted that many government projects and jobs in the construction sector has been hard at work Foreigners possible. So when the government requires the Immigration Service, the detailed regulations to implement the law on foreigners are not allowed.

\section{Account opening requirements for foreign natural persons}

If the applicant is an individual external current account, while observing the conditions of Iranian individuals also must meet the following requirements. Have a valid residence permit Provide a valid passport (replacing the original birth certificate) The foreign natural persons as refugees in Iran live under certain rules and blue card issued by the Ministry of Interior are also allowed to open a current account at the banks are not. Current account opened in the name of those foreign nationals with visa (tourist or temporary tourist or quarterly) and enters the country without a valid residence permit is not possible. Customer approval is possible. Meanwhile, the Central Bank of the Islamic Republic of Iran is a commitment to convert the currency of such accounts will be currency, the rial balance accounts and deposit accounts opened prior to the order mentioned above, respectively. 1 property immovable property which cannot be moved from one location to another, including the deployment or by human action, so that the transmission causing damage or defect in the property or its location. 2 movable properties: objects that may be transported from one location to another without damage to itself or place them into Comes. Movable property into three categories: 1 consumer movable property: the property that effect, partially or completely lost 2. Non-expendable property, real property and tangible change that without losing the original specifications can be they are frequently used. 3 consumer goods as the property of non-expendable property that are similar in appearance, but in terms of the nature and Nature or low value and adjusted to account for nonexpendable property is not necessary bills. Account all of the property, in various forms, maintenance and verification are based on Article 4 Regulations state property subject to legal rules, regulations, contracts and all of them are true. Under existing rules, the various competent authorities are allowed to hold, handle and control are public property. This In addition to government authorities, the owner of the property, including the Ministry of Economic Affairs and Finance, Audit Court And the National Audit Office and other competent authorities to investigate their role in this regard, as discussed here: 1 Ministry of Economy and Finance: According to Article 106 of the Regulations of state property, the primary responsibility for investigating, monitoring and Centralize the responsibility of the Ministry of Economic Affairs and Finance is considered movable property. According to the article, the ministry is allowed in cases where it detects, accounts and property of ministries and government agencies to appropriate ways to address the aforementioned devices must be cooperation and facilities necessary. Office of State property, in order to carry out these responsibilities, the monitor and focusing public property accounts, Ministry of Economic Affairs and Finance, the department has been established under the Office of State property. Property in accordance with Article 16 of Regulation The most important tasks of the State General Administration as follows: 1 receiving invoices and documents relating to property 2 bills dealing with property and the principle of ministries and government agencies and register it with the complete corresponding offices. 3 officers indicted request in accordance with the tasks entrusted to their responsibility in the administrative and judicial authorities in the event of crime or offense. 4 officers deployed to departments and public institutions to deal with property holdings in appropriate situations. Financial Controller, Ministry of Economic Affairs and Finance accountability measures to create networks that are deployed in government agencies, Attempt to preserve, protect and control its property account. Financial Controller by virtue of an order of the Ministry of Economy and Finance of registered nurses qualified to provide supervision and coordination of Implementation of the Financial Regulation and computational ministries and agencies and state-owned companies and local executive agencies and non-governmental organizations and public institutions to be appointed. Under the law stipulates, among other duties, regulatory and accounting, auditors, responsible for keeping track of property Are responsible for monitoring the state of the property. To carry out this responsibility, the following tasks are the responsibility of auditors: 1 investigation and evidence collection bills of property received and sent to the respective owners. 2. Monitoring the delivery and development of the property owners and signature collection if the delivery and development 3 Investigation into account the total tenure of property owners. 4 th address of the property is delivered in cases where the Ministry of Economy and Finance. Errors and property crimes reported during the 5 th and error handling are not known for their fields or mass Are the property of the government ministry or institution and Administration 6 agreed to remove the property from the fields of social account the effect of the sale or transfer or fire or theft or Similar events were collected from captured out. 2 state, however, assume responsibility for monitoring and auditing the accounts of state property Ministry of Economic Affairs and Finance But this will not be related devices disclaimer. In general, according to Article 106 of Regulation 4 State property preservation and maintenance responsibility for the Ministry of Economic Affairs and the State Real Property Account In addition, according to Article 114 of the Finance Act, public accounting, preservation and protection of all immovable property Only the device that belongs to the Committee of Ministers, government agencies are able to use this Have to leave our property.

\section{Conclusion}

Immovable property transactions not recorded in the legal system will be declared void. All transactions relating to immovable property in accordance with documented recurrent registered real estate transaction and deputy to the law and persons Sales will be recognized valid and complete. Claims relating to property other Movable and immovable property under the jurisdiction of the court proceedings in which it is located. The extent of government agencies, diversity and sheer volume of public property, displacement and changes in the volume of assets and properties of new technologies, including the factors that need to be state property system requires review. The design of the system should have knowledge of management information systems (MIS) systems; inventory control, etc. should be considered. 


\section{Acknowledgement}

With all the efforts of Mr. Professor Mahmoud Larry in preparing this article, I would appreciate the help.

\section{References}

[1] Schindler, D (1979), "The International committee of the Red Cross and Human Rights," InternationalReview of the Red Cross, pp. 3-14. http://dx.doi.org/10.1017/S0020860400066353.

[2] Meron, Theodor (1988), "Draft Model Declaration in Internal Sterfe", International Review of, pp. 59-76.

[3] Consistory, N (2009), property and ownership, Tehran, emission rate, the twenty-sixth edition, pp. 48 and 49.

[4] Imam, H (2000), Civil Rights, Tehran, bookstore Fayed, Nineteenth Edition, Vol. I, pp. 34 to 35.

[5] mmtaz, J(2002), "the protection of individual human rights and humanitar ian law in national crises." Bulletin of the Center for International Studies, Faculty of Law and Political Sciences, Tehran University, the third year, pp. 32-31, pp. 17-16.

[6] Commentary, I(1925) Geneva Convention for the Amelioration of the Condition of the Wounded and sick inArmed Aforces in the Field, Geneva, ICRC Jean s.pictet, (ed), p. 5.

[7] The Commission of the European Communities, Commission Recommendation of 6 May 2003 Concerning the Definition of Micro, Small and Medium-sized Enterprises, Official Journal of the European Union L124, Vol. 46, pp. 36-41, p. 39.

[8] Teruel PJ and P. Martinez-Solano (2007), Effects of Working Capital Management on SME Profitability, International Journal of Managerial Finance, Vol. 3, No. 2, pp. 164-177. http://dx.doi.org/10.1108/17439130710738718.

[9] Lazaridis I. and D. Tryfonidis(2006), Relationship Between Working Capital Management and Profitability of Listed Companies in the Athens Stock Exchange, Journal of Financial Management and Analysis, Vol.19 (1), pp. 26-35.

[10]Jose ML, C. Lancaster, and JL Stevens (1996), Corporate Returns and Cash ConversionCycles, Journal of Economics and Finance. 20 (1), pp. 33-46. http://dx.doi.org/10.1007/BF02920497.

[11]Deloof M (2003), Does Working Capital Management Affect Profitability of Belgian Firms? Journal of Business, Finance and Accounting, 30, pp. 573-587. http://dx.doi.org/10.1111/1468-5957.00008.

[12]Stoner E., AJ Stagliano(1997), A Survey of US Manufacturers on Implemention of ABC, Journal of Cost Management, pp.39-41. 